\title{
Early-years future teachers' mathematical beliefs as determinants of performance in primary mathematics
}

\author{
Adeneye Olarewaju Awofala ${ }^{1 *}$, Oludola Sarah Sopekan² \\ ${ }^{1}$ Department of Science and Technology Education, University of Lagos, Nigeria \\ ${ }^{2}$ Department of Arts and Social Sciences Education, University of Lagos, Nigeria \\ *Corresponding author: aawofala@unilag.edu.ng
}

ARTICLE INFO

Article history:

Received: 4 December 2019

Revised: 4 February 2020

Accepted: 7 February 2020

Published online: 28 February

2020

Published regularly: February

2020

Keywords:

Early-years future teachers, mathematical beliefs, performance, primary mathematics

\section{ABSTRACT}

One construct that lies in between the cognitive and affective domains of mathematics education is belief and this concept is rarely investigated in the Nigerian mathematics education community. Thus, an investigation of early-years future teachers' mathematical beliefs as determinants of performance in primary mathematics within the blueprint of the quantitative method of the descriptive survey research design was conducted. Three research questions were addressed and secondary data relating to performance in mathematics of 320 early-years future teachers were retrieved from their records at the Department of Arts and Social Sciences Education, University of Lagos, Nigeria. One other instrument labeled Mathematical Beliefs Scale was employed for the collection of key data connected to the mathematical beliefs. The collected data were condensed and explored with the principal components factor analysis, multiple regression analysis, and independent samples t-test. Results showed that mathematical beliefs measured using the Mathematical Beliefs Scale are a multidimensional construct with fourfactor structure: emotional and developmental commitment in learning of mathematics; self-assurance and philosophies concerning one's subjective mathematical aptitude; beliefs about mathematics; and mathematical problem-solving beliefs. These factors show adequate and excellent reliabilities as computed using Cronbach alpha. Also, gender was not a factor in early-years future teachers' mathematical beliefs even at the subscale level and the four factors of the mathematical belief scale predicted early-years future teachers' performance in primary mathematics. In line with these results, it is recommended that earlyyears future teachers be taught in a constructivist manner so that they can imbibe constructivist beliefs capable of engendering better learning of mathematics.

(C) 2020 Universitas Muhammadiyah Surakarta

\section{Introduction}

One construct that lies in between the cognitive and affective domains of mathematics education is a belief (Boz, 2008; Goldin, Rösken, \& Törner, 2009). Beliefs are characterized by varied definitions. Some researchers have viewed beliefs as an addendum to knowledge (Furinghetti, 1996; Pajares, 1992) in this case subjective knowledge, some consider beliefs

To cite this article:

Awofala, A. O., \& Sopekan, O. S. (2020). Early-years future teachers' mathematical beliefs as determinants of performance in primary mathematics. JRAMathEdu Journal of Research and Advances in Mathematics Education), 5(1), 54-68. doi:https://doi.org/10.23917/jramathedu.v5i1.9433 
as part of attitudes (Grigutsch, 1998), and some reflect on beliefs as part of conceptions (Thompson, 1992) in this case conscious beliefs. However, beliefs are considered as an appendage to personal metacognition (Schoenfeld, 1987) in which conscious beliefs are cognitively based. Skott (2010) defined beliefs as "deeply personal, conscious or unconscious, value-laden, mental constructions that carry a subjective truth-value and are the result of experiences gained over prolonged periods" (p.194). Pehkonen and Törner (1996) describe four kinds of functions of beliefs which may also go for the characterizations of beliefs. First, beliefs constitute a contextual adaptable structure of our awareness, philosophy, and engagements. Second, beliefs serve as pointers for pedagogical discourse. Third, beliefs are construed as a lethargy dynamism capable of working contrary to transformation. Finally, beliefs possess a predicting charisma.

Nespor (1987) outlined the four characteristics of belief which distinguish it from knowledge: existential presupposition (are individual truths connected to the philosophies in deities or extra-terrestrials established on fortuitous or powerful familiarity), alternativity (i.e. generating fictional worlds deprived of unswerving familiarity), emotional and judgmental loading, and intermittent configuration. The four subdivisions of learners' beliefs given by McLeod (1992) include beliefs about mathematics; beliefs about self; beliefs about teaching; and beliefs about social context. Beliefs about mathematics relate to the thought that mathematics is challenging and that it is rule-based. Beliefs about self connote confidence and poise in mathematical learning and provenances for attainment and disappointment in mathematics. Beliefs about teaching relate to the philosophies that a teacher should engage in order to assist a student to be proficient in mathematics. Beliefs about social context relate to the philosophies that learning mathematics is competitive and that other stakeholders such as parents and relatives outside the four walls of the school have a weighty impact on student mathematics learning. These categorizations are vital in that they show the multidimensionality of students' beliefs and how these beliefs might affect learning. Truly, Schoenfeld (1983) supported the view that diverse factors of beliefs govern an individual's rational actions.

The spectrum of an individual's beliefs is very wide and they are usually grouped into clusters of beliefs (Pehkonen \& Pietilä, 2003) called belief systems. Beliefs system is a metaphor for describing how one's beliefs are organized in a cluster, generally around a particular idea or object (Thompson, 1992). Belief systems are philosophies structured in an emotional form, but not automatically rationally (Rokeach, 1968). In a belief system, the strength of beliefs varies with some being central and others being peripheral (Boz, 2008). The centrality of belief makes it resilient to modification (Smith, 2014). The emotional facet of beliefs impacts the function and connotation of individual beliefs within the belief system (Pehkonen \& Pietilä, 2003). Beliefs epitomize the loose type of implicit knowledge (Pehkonen \& Pietilä, 2003) and conflicts among beliefs may exist and these may diminish as individuals gain more experience.

Literature is replete with four different sources of beliefs (Ambrose, 2004; Furinghetti, \& Pehkonen, 2002). First, beliefs can be developed and altered through emotion-filled experiences that happen through learning, intermingling or articulating goals and yearnings. Second, beliefs can be socially transferred or they can be transferred by others, especially by authorities in which people often adopt them un-mirrored. Third, individuals can reproduce their beliefs and become conscious of formerly buried beliefs. Finally, individuals can have understandings or images that help them to fix beliefs to one another and, thus, to form more expanded attitudes. In the literature, two types of beliefs exist about mathematics and these are students' mathematical beliefs and teachers' mathematical beliefs. The latter connotes the systems of belief strongly caught by teachers 
during pedagogical discourse in mathematics (Handal, 2003) whereas the former refers to those belief systems held by students about math and themselves as learners of mathematics (Awofala \& Awolola, 2011). Students' mathematical belief is defined as the tacitly or overtly caught idiosyncratic formations students embrace as being true in relation to the trio of mathematics education, mathematics learners, and mathematics class milieu (Op't Eynde \& De Corte, 2003).

Teachers' mathematical beliefs consist of philosophies regarding the nature of mathematics, the occurrence of pedagogical discourse in mathematics, and the ideal occurrence of pedagogical transactions in the classroom (Çam, 2015; Ernest, 1989a, 1989b; Purnomo, Suryadi, \& Darwis, 2016; Purnomo, 2017; Siswono, Kohar, Kurniasari, \& Hartono, 2018; Thompson, 1991; Xenofontos, 2018; Xie, \& Cai, 2018). It is clear that teachers' beliefs play a formidable function in their pedagogical transactions and enactment of program restructuring (Handal, \& Herrington, 2003; Kagan, 1992; Pajares, 1992), but remains unclear if teachers' beliefs impact pedagogical comportment or if their in-class transactions impact the beliefs they hold (Purnomo, 2017; Buzeika, 1996). While a teacher's belief is vigorous and strong (Pajares, 1992), impervious to modification (Çam, 2015; Kagan, 1992; Shi, Zhang, \& Lin, 2014; Block \& Hazelip, 1995; Awofala \& Awolola, 2011), acts as barricades to vicissitudes in pedagogical transactions (Fullan, \& Stegelbauer, 1991; Purnomo, 2017; Awofala \& Awolola, 2011), and functions as sifters of innovative knowledge (Nespor, 1987; Pajares, 1992; Xie, \& Cai, 2018), teachers' beliefs may ease or obstruct program restructuring (Koehler, \& Grouws, 1992; Sosniak, Ethington, \& Varelas, 1991; Burkhardt, Fraser, \& Ridgway, 1990; Awofala \& Awolola, 2011).

Even though teachers' mindfulness of students' mathematical beliefs is central, it may be equally imperative for students to be mindful of their own beliefs about mathematics. Students' beliefs about mathematics and themselves as learners of mathematics have been a subject of intense research by mathematics educators (Op't Eynde, \& De Corte, 2003; Op't Eynde, De Corte, \& Verschaffel, 2002; Stage, \& Kloosterman, 1992). Students often hold the erroneous beliefs that "math is computation", "there is always a rule to follow in mathematics" and that "learning mathematics is only memorizing" which may undermine their motivation to learn math. While students' learning experiences are likely to add to their beliefs about what it takes to learn mathematics, students' beliefs about mathematics are likely to impact how they view new mathematical learning experiences thereby creating a cyclic relationship between students' beliefs and learning.

Students' "mathematical world view" (Schoenfeld, 1985) or beliefs system often affect students' learning and this world view has been conceptualized in three perspectives: traditional, formalist, and constructivist (Dionne, 1984). The traditional perspective sees mathematics as rules-based in which engaging in mathematics is engaging in calculations and utilizing strategies, processes, and formulas. The formalist perspective views mathematics as not different from logic and precision in which engaging in mathematics is engaging in laborious verifications, utilizing a clear-cut and exact language and adopting coalescing conceptions. The constructivist perspective views mathematics as a productive practice in which engaging mathematics is growing cognitions and synthesizing procedures and formulas from the actuality that are amenable to personal creation. Ernest (1991) postulates three main philosophical conceptions of nature of mathematics: instrumentalist, problem-solving and Platonist which correspond to the Dionne (1984) perspectives earlier mentioned. The instrumentalist sees mathematics as an assemblage of rubrics and skills needed for the accomplishment of a specific objective (Handal, 2003). The Platonists see mathematics as a static but unified body of certain rules (Ernest, 1991) that are discoverable and not acquiescent of subjective formation (Handal, 
2003). In problem-solving mathematics is seen as a constant development of inquest that is open to reconsideration (Handal, 2003) or math being a dynamic human invention.

A growing body of literature indicates that pre-service teachers hold sets of beliefs more traditional than reformist concerning the teaching of mathematics as they hold intellectual configurations overestimating their ability to cram and not internalize rubrics and processes during mathematical pedagogical discourse (Handal, 2003). Some of the conservative beliefs are highlighted as follows. Pre-service teachers hold the belief that mathematics thrives on rules and procedures to be learned by heart and math can be dichotomized into "completely right or completely wrong" (Benbow, 1993, p. 10) answer. Mathematics requires neatness and speed, and that there is always the best way to solve a problem (Civil, 1990). "Some people have a mathematical mind and some don't", "mathematics requires logic, not intuition", and "you must always know how you got the answer" (Frank, 1990, p. 11). "Math involves practice and memorization and that it is innate" (Foss \& Kleinsasser, 1996, p. 438) and school mathematics should be immersed in memorization of proofs and rubrics (Southwell \& Khamis, 1992). The research on inservice teachers is somewhat pervasive than pre-service teachers. Teachers hold the belief that mathematics should be used to replicate the authentic world, that mathematics is inborn, and that a mathematical concept should be explained in more than one representation (Beaton, Mullis, Martin, Gonzalez, Kelly, Smith, 1996). Teachers hold the belief that mathematics should be taught in whole-class discussions with teachers deploying models and adopting manipulatives devoid of calculators during teaching and learning discourse (Anderson, 1997). Teachers view mathematics as a highly sequential and static subject in which students should be grouped based on previous educational attainment to promote deeper paybacks from teaching (Grossman, 1995).

In spite of the avalanche of research on beliefs about mathematics, only few studies have investigated beliefs about mathematics in relation to students' mathematical achievement (Gómez-Chacón, García-Madruga, Rodríguez, Vila, \& Elosúa, 2011; Hacıömeroğlu \& Şahin-Taşkın, 2010; Işıksal, Kurt, Doğan, \& Çakıroğlu, 2007) and these relationships had been inconclusive. The study by Gómez-Chacón, García-Madruga, Rodríguez, Vila, J and Elosúa (2011) found that beliefs about mathematics and beliefs about one's competence were extrapolative of mathematical achievement. The study also reported that there was a momentous constructive association between each dimension of mathematical beliefs and mathematics achievement. House (2006) in a cross-cultural study of the relationship between mathematical beliefs and mathematics achievement in Japan and the United States identified several weighty associations between self-beliefs and mathematics achievement. Learners who view accomplishment in mathematics as a function of hard work and true studying exhibited prowess in achievement scores while those who ascribed accomplishment in mathematics class to good luck were inclined to attain poorer scores in mathematics. Memnun and Katranci (2012) found a significant positive relationship between prospective teachers' beliefs about mathematics and their

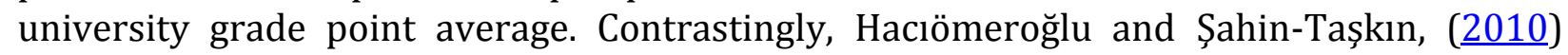
found no significant relationship between elementary prospective teachers' beliefs about mathematics and achievement in mathematics.

Few studies have explored the association between mathematical beliefs and gender and these studies have shown inconclusive findings. While some studies have found significant gender effect on beliefs about math (Memnun \& Katranci, 2012), others have returned no significant effect of gender on beliefs about mathematics (Aksu, 2008; Hacıömeroğlu \& Şahin-Taşkın, 2010). This inconclusive finding warrants further investigation in the present study. However, not too many researches on the relationship 
between beliefs about mathematics and performance in mathematics call for more research in this area as this is a fertile area worth investigating. Thus, this study investigated mathematical beliefs as determinants of early-years future teachers' performance in primary mathematics in Nigeria. This study would be the first to be conducted in Nigeria.

\section{Research Methods}

The study adopted a quantifiable inquiry methodology within the plan of the descriptive survey scheme. The respondents were 320 early-years future teachers (86 men and 234 women) from the Arts and Social Sciences Education Department at the University of Lagos in Lagos State, South-west, Nigeria. Their ages vacillated from 19 to 30 years, with $80 \%$ within the age bracket $\leq 20$ years and $20 \%$ between the age brackets $\mathrm{x}$ such that $21 \leq \mathrm{x} \leq 30$ years. This age distribution is typical of the University of Lagos early-years future teacher education with great magnitudes of "recent school leavers". 93 (29.06\%) were in first year [18 (19.35\%) men, $75(80.65 \%)$ women, Mage $=19.4$ years, SD $=2.3$, age range: 16-25 years]. $79(24.69 \%)$ were in second year [20 (25.32\%) men, 59 (74.68\%) women, Mage $=21.2$ years, $\mathrm{SD}=2.8$, age range: $17-28$ years]. $70(21.88 \%)$ were in third year [20 $(28.57 \%)$ men, $50(71.43 \%)$ women, Mage $=22.3$ years, $\mathrm{SD}=3.1$, age range: $18-29$ years] . $78(24.38 \%)$ were in fourth year [28 (35.90\%) men, 50 (64.10\%) women, Mage = 21.3 years, $\mathrm{SD}=2.9$, age range: $19-30$ years].

For data collection, two instruments were used. The Mathematical Beliefs Scale (MBS) otherwise called CreeMat (Gómez-Chacón \& García-Madruga, 2009) was adopted in collecting data connected with early-years future teachers' mathematical beliefs. The MBS needs revalidation since using an adopted scale in its original form in a different context raises questions about the validity and reliability of the scale. So it is always better to reexamine the scale validity and reliability in a new setting for credibility and cross-cultural generalization. The secondary data connected with performance in primary mathematics were taken from the early-years future teachers' records in the Department of Arts and Social Sciences Education, Faculty of Education, University of Lagos, Nigeria. The MBS contained 13 items hinged on a 5-point modified Likert scale vacillating from: Strongly agree -4 , Agree -3 , Disagree -2 , Strongly disagree -1 , to Undecided -0 . The Cronbach alpha reliability coefficient of the MBS computed was 0.84 . The authors in conjunction with four research assistants oversaw the administration of the MBS to the target sample in their respective classes. Data collected with the scale were condensed and examined through principal components factor analysis, analysis of variance (ANOVA), Pearson moment correlation, and multiple regression analysis.

\section{Results and Discussion}

\section{Research Question One}

What is the factor structure of the mathematical beliefs scale among Nigerian early-years future teachers?

\section{Preliminary analyses before Exploratory Factor Analysis (EFA)}

The factorial configuration of the 13 items MBS was determined using the principal components factor analyses (PCA) with varimax rotation. Before this, the data were screened for outliers and missing values. However, there was no missing value for the 320 participants and no concern about normality, linearity, multicollinearity, and singularity. 
Table 1 showed the descriptive statistics for the total score and four subscale scores for the sample. The skewness and kurtosis levels were within acceptable ranges. The intercorrelations among the subscales vacillated from 0.20 to 0.34 , which were statistically significant.

Table 1

Scale-level descriptive statistics for MBS total and subscale scores

\begin{tabular}{lcccccc}
\multicolumn{7}{c}{ Sample $(\mathrm{n}=320)$} \\
\hline EDCLM & $\mathrm{M}$ & SD & Skewness & Std. Error & Kurtosis & Std. Error \\
SPSMA & 2.91 & 0.73 & 0.62 & 0.13 & -0.51 & 0.27 \\
BAM & 2.60 & 0.74 & 0.58 & 0.13 & -0.33 & 0.27 \\
MPSB & 2.89 & 2.89 & 0.93 & -0.73 & -0.80 & 0.27 \\
MAT.BEL Total & 2.75 & 275 & 0.81 & -0.73 & -0.80 & 0.27 \\
\hline
\end{tabular}

EDCLM = emotional and developmental commitment in learning of mathematics; SPSMA=self-assurance and philosophies concerning one's subjective mathematical aptitude; BAM= beliefs about mathematics; MPSB= mathematical problem-solving beliefs; MAT.BEL Total=Mathematical Belief Total. Note. Scale minimum = 1.00; scale maximum $=5.00$.

The preliminary investigation showed the adequacy of the input data as confirmed via Bartlett's test of sphericity, $\chi^{2}=5.463 \mathrm{E} 3 ; d f=78 ; p<.001$, which shows the identity nature of the correlation matrix. The Kaiser-Meyer-Olkin measure of sampling adequacy (MSA) was within tolerable range (values $\geq .60$ ) with an estimate of .85 . All of the variables were greater than the starting point value (.60) of MSA which vacillated from .720 to .906. Virtually all of the partial correlations were trivial as shown via the anti-image correlation matrix. These procedures gave rise to the decision that the collection of 13 items of MBS was appropriate for PCA.

\section{Exploratory Factor Analysis of MBS}

Principal components analysis (PCA) was conducted to fix the number of factors to be retained in the MBS subcategories based on the conjecture of a varimax interaction between factors. The initial pre-rotation resulted in four factors with eigenvalues $>1$ (Kaiser, 1960; Tabachnick \& Fidell, 2007), accounting for approximately 85.32\%. The configuration of dimension loadings of the un-gyrated dimension model was hypothetically not significant and thus, was problematic to understand. Thereafter, the study advanced to revolve the dimension matrix orthogonally to attain a straightforward and notionally more significant solution. Varimax gyration was used for the orthogonal solution. By rotating four factors, the total percentage of variance accounted for remained at $85.32 \%$. An examination of Cattel's scree test produced a four-factor solution (Figure 1)(Cattel, 1996). This seemed to support the original theory on which the instrument is based which had proposed four factors. For interpretational clarity, a salient loading (Gorsuch, 1983) of 0.40 was selected as one that is sufficiently high to assume the existence of an item-factor relationship (Awofala \& Anyikwa, 2014). The first factor, which accounted for $41.10 \%$ of the variance (eigen value=5.34), was labeled Emotional and developmental commitment in the learning of mathematics and this factor included 3 items. The second factor, Selfassurance, and philosophies concerning one's subjective mathematical aptitude included 4 items and accounted for $22.32 \%$ of the variance (eigenvalue=2.90). The third factor, Beliefs about mathematics included 3 items and accounted for $11.99 \%$ of the variance (eigenvalue=1.56). The fourth factor, mathematical problem solving beliefs included 3 items and explained $9.92 \%$ of the discrepancy (eigenvalue=1.30). The study showed that all the communalities $\left(\mathrm{h}^{2}\right)$ of the PCA fulfilled the smallest prerequisite of being $>0.50$ and 
these vacillated from 0.59 to 0.98 . Below is the graph of the scree plot (Figure 1) which shows the eigenvalue alongside the dimension number and it is indicative of a fourdimension model.

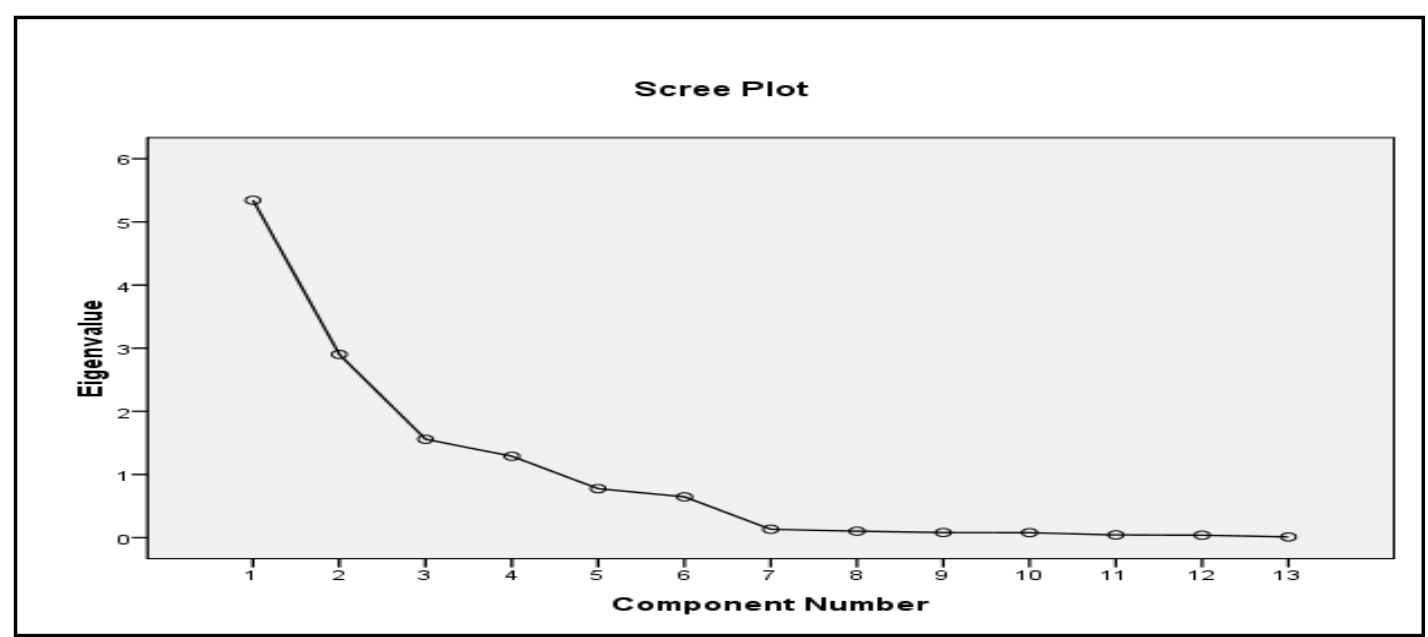

Figure 1.Cattell scree plot displaying the number of dimensions and eigenvalues of the correlation matrix.

Table 2 displayed the factor loadings for the orthogonal four-factor model of MBS. All items loaded .67 and above on their primary factor and none of the secondary loadings exceeded 30 .

In the present study, the emotional and developmental commitment in learning of mathematics refers to the motivating desire to learn mathematics in the face of difficulties; Self-assurance and philosophies concerning one's subjective mathematical aptitude is a learner's acuity of his/her capability to achieve remarkable grades and his/her reassurance that he/she can disentangle challenges in mathematics; Beliefs about mathematics and mathematical problem solving is the individual value decisions that are molded by the previous practices of the person in mathematical problem solving situation; and Mathematical beliefs deal with the personal value judgment and philosophies regarding mathematics learning in its entirety.

\section{Research Question Two}

Is there any significant influence of gender on early-years future teachers' mathematical beliefs?

Concerning the aggregate mathematical beliefs score, the female early-years future teachers in Table 3 pooled a marginally lower mean score $(M=2.79, S D=0.55)$ than their male equivalents $(\mathrm{M}=2.80, \mathrm{SD}=0.50)$. Thus, this marginal disparity in mean score was not computationally meaningful $\left(\mathrm{t}_{318}=.13, \mathrm{p}=.90\right)$. As contained in Table 3 the female earlyyears future teachers pooled a little lower mean score $(\mathrm{M}=2.88, \mathrm{SD}=0.77)$ in emotional and developmental commitment in the learning of mathematics than their male equivalents $(\mathrm{M}=3.01, \mathrm{SD}=0.58)$ and this little disparity in mean score was not computationally meaningful $\left(\mathrm{t}_{318}=1.09, \mathrm{p}=.28\right)$. 
Table 2

Item Loadings and Communalities $\left(\mathrm{h}^{2}\right)$ for Principal Components Analysis on MBS Items Depicting the Four-Factor Model

\begin{tabular}{|c|c|c|c|c|c|c|}
\hline \multicolumn{2}{|r|}{ Item } & \multicolumn{5}{|c|}{ Factor Loadings } \\
\hline & & 1 & 2 & 3 & 4 & $\mathrm{~h}^{2}$ \\
\hline & $\begin{array}{l}\text { Emotional and developmental commitment in the } \\
\text { learning of mathematics }(\alpha=.87)\end{array}$ & & & & & \\
\hline 1. & I work hard in Math (subject). & 0.674 & 0.027 & 0.022 & -0.286 & 0.592 \\
\hline 2. & If I make mistakes, I work to correct them & 0.775 & 0.36 & -0.33 & -0.272 & 0.620 \\
\hline 3. & I like to invent new problems. & 0.702 & 0.031 & 0.005 & -0.0292 & 0.595 \\
\hline & $\begin{array}{l}\text { Self-assurance and philosophies concerning one's } \\
\text { subjective mathematical aptitude }(\alpha=.92)\end{array}$ & & & & & \\
\hline 4. & I learn math quickly. & 0.012 & 0.935 & 0.074 & 0.108 & 0.940 \\
\hline 5. & When I am asked to solve math problems, I get nervous. & 0.081 & 0.953 & 0.133 & 0.129 & 0.971 \\
\hline 6. & I feel confident when I study or work on math & 0.088 & 0.956 & 0.167 & 0.084 & 0.986 \\
\hline 7. & $\begin{array}{l}\text { I feel happy when I solve math problems. } \\
\text { Beliefs about mathematics }(\boldsymbol{\alpha =} \mathbf{. 9 0 )}\end{array}$ & 0.088 & 0.941 & 0.136 & 0.090 & 0.962 \\
\hline 8. & Math allows us to understand the world we live in better. & 0.187 & 0.205 & 0.974 & 0.127 & 0.961 \\
\hline 9. & $\begin{array}{l}\text { Math consists of concepts and procedures that we have to } \\
\text { memorize }\end{array}$ & 0.089 & $-\overline{0}-204$ & 0.944 & 0.026 & 0.908 \\
\hline & Everyone can learn math & 0.189 & $-\overline{0}-280$ & 0.971 & 0.194 & 0.953 \\
\hline & Mathematical problem-solving beliefs $(\alpha=.94)$ & & & & & \\
\hline & $\begin{array}{l}\text { When I cannot solve a math problem quickly, I keep on } \\
\text { trying. }\end{array}$ & 0.189 & $-\overline{0}-283$ & 0.141 & 0.900 & 0.930 \\
\hline 12. & I prefer challenging tasks to learn new things. & 0.087 & $-\overline{0}-276$ & 0.143 & 0.903 & 0.930 \\
\hline 13. & $\begin{array}{l}\text { Math should not place much importance on problem- } \\
\text { solving. }\end{array}$ & 0.076 & $-\overline{0}-286$ & 0.118 & 0.910 & 0.944 \\
\hline
\end{tabular}

Table 3

Independent samples t-test analysis of early-years future teachers' mathematical beliefs dimensions based on gender

\begin{tabular}{|c|c|c|c|c|c|c|c|}
\hline Variable & Gender & $\mathrm{N}$ & Mean & SD & $\mathrm{df}$ & $\mathrm{t}$ & $\mathrm{p}$ \\
\hline EDCLM & $\begin{array}{c}\text { Female } \\
\text { Male }\end{array}$ & $\begin{array}{c}234 \\
86\end{array}$ & $\begin{array}{l}2.88 \\
3.01\end{array}$ & $\begin{array}{l}0.77 \\
0.58\end{array}$ & 318 & 1.41 & 0.16 \\
\hline SPSMA & $\begin{array}{c}\text { Female } \\
\text { Male }\end{array}$ & $\begin{array}{c}234 \\
86\end{array}$ & $\begin{array}{l}2.63 \\
2.53\end{array}$ & $\begin{array}{l}0.69 \\
0.87\end{array}$ & 318 & 1.09 & 0.28 \\
\hline BAM & $\begin{array}{c}\text { Female } \\
\text { Male }\end{array}$ & $\begin{array}{c}234 \\
86\end{array}$ & $\begin{array}{l}2.99 \\
2.79\end{array}$ & $\begin{array}{l}0.87 \\
0.74\end{array}$ & 318 & 1.14 & 0.26 \\
\hline MPSB & $\begin{array}{c}\text { Female } \\
\text { Male }\end{array}$ & $\begin{array}{c}234 \\
86\end{array}$ & $\begin{array}{l}2.79 \\
2.66\end{array}$ & $\begin{array}{l}0.74 \\
0.99\end{array}$ & 318 & 1.24 & 0.22 \\
\hline MAT.BEL & $\begin{array}{c}\text { Female } \\
\text { Male }\end{array}$ & $\begin{array}{c}234 \\
86\end{array}$ & $\begin{array}{l}2.79 \\
2.80\end{array}$ & $\begin{array}{l}0.55 \\
0.50\end{array}$ & 318 & 0.13 & 0.90 \\
\hline
\end{tabular}

EDCLM = emotional and developmental commitment in learning of mathematics; SPSMA=self-assurance and philosophies concerning one's subjective mathematical aptitude; BAM= beliefs about mathematics; MPSB= mathematical problem-solving beliefs; MAT.BEL Total=Mathematical Belief Total.

Table 3 indicated that the male early-years future teachers pooled marginally lower mean score $(M=2.53, S D=0.87)$ in self-assurance and philosophies concerning one's subjective mathematical aptitude than their female equivalents $(M=2.63, S D=0.69)$. The 
disparity was not computationally meaningful $\left(\mathrm{t}_{318}=1.09, \mathrm{p}=.28\right)$. Concerning beliefs about the mathematics subscale, the female early-years future teachers pooled marginally lower mean score $(M=2.86, S D=0.95)$ than their male equivalents $(M=2.99, S D=0.87)$. But, this disparity in mean score was computationally not meaningful $\left(\mathrm{t}_{318}=1.14, \mathrm{p}=.26\right)$. In addition, female early-years future teachers pooled marginally higher mean score $(M=2.79$, $\mathrm{SD}=0.74)$ in mathematical problem solving beliefs than their male equivalents $(M=2.66$, $\mathrm{SD}=0.99)$. This variance in mean score was computationally not meaningful $\left(\mathrm{t}_{318}=1.24\right.$, $\mathrm{p}=.22$ ). Therefore, the study reached a decision that gender was not a contributor to disparity in early-years future teachers' mathematical beliefs even at its subscale levels.

\section{Research Question Three}

What are the composite and relative contributions of mathematical beliefs factors to the explanation of the variance in the early-years future teachers' performance in primary mathematics?

The predictors (EDCLM, SPSMA, BAM, and MPSB) as contained in Table 4 mutually produced a coefficient of multiple regression of .505 and a multiple correlation square of .255 to the explanation of discrepancy in early-years future teachers' performance in primary mathematics. The implication is that $25.5 \%$ of the overall disparity in performance in primary mathematics was explained by the blend of the four predictors. The analysis of variance of the multiple regression data produced an $F$-ratio value $\left(F_{(4,315)}=26.99 ; p<.001\right)$ significant at 0.001 level. This showed that the regression model is a good fit for the data.

The outcomes of the marginal contributions showed that SPSMA was the most potent significant positive contributor to the prediction of early-years future teachers' performance in mathematics $(\beta=.242, t=4.66, p=.000)$. BAM made the next significant positive contribution to the prediction of early-years future teachers' performance in mathematics $(\beta=.210, t=3.97, p=.000)$. EDCLM made the next significant positive contribution to the prediction of early-years future teachers' performance in mathematics $(\beta=.173, t=3.40, p=.001)$. MPSB made the least significant positive contribution to the prediction of early-years future teachers' performance in mathematics $(\beta=.132, t=2.48$, $p=.014)$. The standardized coefficients revealed that the regression model: performance in mathematics predicted $=0.867+(0.182 \times$ EDCLM $)+(0.250 \times$ SPSMA $)+(0.174 \times$ BAM $)+$ $(0.125 \times$ MPSB $)$.

Table 4

Model summary, coefficient, and t-value of multiple regression analysis of mathematical beliefs dimensions and the outcome measure (performance in primary mathematics)

Model summary

Multiple $\mathrm{R}=.505$; Multiple $\mathrm{R}^{2}=.255$; Multiple $\mathrm{R}^{2}$ (Adjusted) $=.246$

Standard Error Estimate= $0.67 ; F=26.99, p<.001$

\begin{tabular}{lccccc}
\hline \multicolumn{1}{c}{ Model } & \multicolumn{3}{c}{ Un-standardized coefficients } & \multicolumn{2}{c}{ Standardized coeff. } \\
\hline & $\mathrm{B}$ & Std Error & Beta & $\mathrm{t}$ & Sig \\
Constant & 0.867 & 2.04 & & 4.25 & 0.000 \\
EDCLM & 0.182 & 0.053 & 0.173 & 3.40 & 0.001 \\
SPSMA & 0.250 & 0.054 & 0.242 & 4.66 & 0.000 \\
BAM & 0.174 & 0.044 & 0.210 & 3.97 & 0.000 \\
MPSB & 0.125 & 0.050 & 0.132 & 2.48 & 0.014
\end{tabular}

EDCLM = emotional and developmental commitment in learning of mathematics; SPSMA=self-assurance and philosophies concerning one's subjective mathematical aptitude; BAM= beliefs about mathematics; MPSB= mathematical problem-solving beliefs. 
The results of this study have shown that the beliefs about mathematics as assessed by the beliefs about mathematics scale is a multidimensional construct. The investigative dimension inquiry utilizing the PCA indicated a four-dimension configuration underlying the assessment tool with adequate internal consistency reliabilities: emotional and developmental commitment in learning of mathematics (3 items; $\alpha=0.87$ ); self-assurance and philosophies concerning one's subjective mathematical aptitude ( 4 items; $\alpha=0.92$ ); beliefs about mathematics ( 3 items; $\alpha=0.90$ ) and mathematical problem solving beliefs ( 3 items; $\alpha=0.94$ ). This is in tandem with Gómez-Chacón \& García-Madruga (2009) the original developer of the scale who determined a multidimensional structure for the scale with adequate internal consistency reliability. The four dimensions arrived at were labelled: Affective and behavioural engagement in mathematical learning; Mathematical confidence and beliefs in one's personal competence; Beliefs about mathematics and mathematical problem-solving; and mathematical beliefs. This multi-dimensional instrument extracted through the scree plot and Kaiser's criterion is implicated by the strong statistical proof that could not be jettisoned. The import of mathematics requires that early childhood pre-service teachers work hard and make mistakes as part of the process of inventing new problems in the mathematics journey. While early childhood preservice teachers sometimes get nervous when solving mathematics, they believe that they should be able to solve mathematics problems quickly and learn to be confident when solving mathematics needed for a better life in the world. They believe that mathematics should not be heavily dependent on problem-solving and that everyone can learn mathematics despite the challenges that may warrant one to keep on trying when solving mathematics problems.

The finding of this study has shown that gender is not a factor in early-years future teachers' mathematical beliefs even at the subscale levels. Thus, there is no basis for segregating male and female early-years future teachers when teaching mathematics as both genders carry equal weight concerning the beliefs about mathematics. This finding seems to buttress the fact that the gender gap in affective domain is closing and can reach a zero-tolerance level as presently being obtained for the cognitive domain in mathematics (Awofala \& Anyikwa, 2014). The parity between male and female early-years future teachers in mathematical beliefs is a welcome development as the world moves to eradicate all forms of prejudices against women orchestrated by cultural and gender stereotypes (Awofala, 2017).

The results shown in Table 4 indicated that $25.5 \%$ of the discrepancy in early-years future teachers' performance in mathematics could be explained by the four independent variables (EDCLM, SPSMA, BAM, and MPSB) altogether. However, $74.5 \%$ of the discrepancy in performance in mathematics was not explainable through the existing data. Thus, it is reasonable to think that other predictors exist which the study did not investigate and can contribute to the explanation of variance in early-years future teachers' performance in mathematics. These results are in agreement with the results of previous studies on the predictive influence of mathematical beliefs on students' performance in mathematics (Gómez-Chacón, García-Madruga, Rodríguez, Vila, \& Elosúa, 2011; Işılksal, Kurt, Doğan \& Çakıroğlu, 2007). The implication of these results is that mathematical beliefs might facilitate early-years future teachers' performance in mathematics as those who hold strong beliefs about mathematics might record higher performance in mathematics. Future teachers need to hold the belief that they can do well in mathematics as a springboard for their high attainment in mathematics learning. Mathematical beliefs of early-years future teachers may not only govern their point of view regarding the mathematical ecosphere but may also have a direct influence on their success in mathematics learning. 


\section{Conclusion}

The mathematical beliefs scale is a multidimensional scale that can be deployed to validly and reliably assess early-years future teachers' mathematical beliefs. The belief about mathematics held by early-years future teachers is not gendered sensitive. Hence, all forms of gender barriers in the way of women should be dismantled since women hold similar beliefs about mathematics with men. Equal preference should be given to both men and women in mathematical pedagogical discourse in the classroom. In conclusion, the present study has shown that mathematical beliefs are good predictors of early-years future teachers' performance in primary mathematics. This is important as early-years future teachers hold varied beliefs that may make or mar their performance in mathematics. Early-years future teachers should be taught in a constructivist way so that they can imbibe constructivist beliefs capable of engendering better learning of mathematics.

\section{Acknowledgment}

The authors acknowledged the support of the early-years future teachers that gave themselves willingly for the study. Thank you and more powers to your elbow.

\section{Bibliography}

Aksu, H. H. (2008). Öğretmen adaylarının matematik öğretimine yönelik öz-yeterlilik inançları. Abant İzzet Baysal Üniversitesi Eğitim Fakültesi Dergisi, 8(2), 161-170.

Ambrose, R. (2004). Initiating change in prospective elementary school teachers' orientations to mathematics teaching by building on beliefs. Journal of Mathematics Teacher Education, 7(2), 91-119. https://doi.org/10.1023/B:JMTE.000002 $\underline{1879.74957 .63}$

Anderson, J. (1997). Teachers' reported use of problem-solving teaching strategies in primary mathematics classrooms. In F. Biddulph \& K. Carr (Eds.), People in mathematics education. Proceedings of the 20th Annual Conference of the Mathematics Education Research Group of Australasia (pp. 50-57). Rotorua, NZ: MERGA.

Awofala, A. O. A. \& Anyikwa, B. E. (2014). Assessing Adult Learner's Numeracy as Related to Gender and Performance in Arithmetic. Journal of New Approaches in Educational Research (NAER Journal), 3(2), 83-92. https://doi.org/10.7821/naer.3.2.83-92

Awofala, A. O. A. (2017). Assessing senior secondary school students' mathematical proficiency as related to gender and performance in mathematics in Nigeria. International Journal of Research in Education and Science, 3(2), 488-502. https://doi.org/10.21890/ijres.327908

Awofala, A. O. A., \& Awolola, S. A. (2011). Coping with new mathematics teacher's beliefs in a conflicting milieu of curriculum transform. In I. O. S. Abonyi (Ed.) Proceedings of 52nd Annual Conference of the Science Teachers Association of Nigeria on Reforms in Science, Technology, Engineering and Mathematics (pp. 309-315). HEBN Publishers Plc.

Beaton, A. E., Mullis, I. V. S., Martin, M. O., Gonzalez, E. J., Kelly, D. L., Smith, T. A. (1996). Mathematics achievement in the middle school years. Boston: Center for the Study of Testing, Evaluation, and Educational Policy, Boston College.

Benbow, R. M. (1993). Tracing Mathematical Beliefs of Preservice Teachers through Integrated Content-Methods Courses. Proceedings of the Annual Conference of the American Educational Research Association. ERIC Document Reproduction Service No. ED 388638. 
Block, J. H., \& Hazelip, K. (1995). Teachers' beliefs and belief systems. In L. W. Anderson (Ed.), International encyclopedia of teaching and teacher education (2nd ed., pp.25-28). New York: Pergamon Press.

Boz, N. (2008). Turkish Pre-Service Mathematics Teachers' Beliefs About Mathematics Teaching. Australian Journal of Teacher Education, 33(5), 66-80. https://doi.org/10.14221/ajte.2008v33n5.5

Burkhardt, H., Fraser, R., \& Ridgway, J. (1990). The dynamics of curriculum change. In I. Wirszup \& R. Streit (Eds.), Development in school mathematics education around the world (pp. 3-29). Reston, VA: NCTM.

Buzeika, A. (1996). Teachers' beliefs and practice: The chicken or the egg? In P. C. Clarkson (Ed.), Technology in mathematics Education. Proceedings of the 19th Annual Conference of the Mathematics Education Research Group of Australasia (pp. 93-100). Melbourne: MERGA

Çam, A. (2015). Primary Pre-Service Teachers' Epistemological Beliefs and their Teaching and Learning Experiences. Eurasia Journal of Mathematics, Science \& Technology Education, 11(2), 381-390. https://doi.org/10.12973/eurasia.2015.1351a

Cattel, R. B. (1996). The scree test for the number of factors. Multivariate Behavioral Research, 1(2), 245-276. https://doi.org/10.1207/s15327906mbr0102 10

Civil, M. (1990). "You only do Math in Math": A Look at Four Prospective Teachers' Views about Mathematics. For the Learning of Mathematics, 10(1), 7-9. Retrieved From https://www.jstor.org/stable/40247968

Dionne, J. (1984). The perception of mathematics among elementary school teachers. In J. Moser (Ed.), Proceedings of the 6th Annual Meeting of the North American Chapter of the International Group for the Psychology of Mathematics Education (PME) (pp. 223228). Madison (WI): University of Wisconsin.

Ernest, P. (1989a). The impact of beliefs on the teaching of mathematics. In P. Ernest (Ed.), Mathematics teaching: The state of art (pp. 249-254). New York: Falmer.

Ernest, P. (1989b). The knowledge, beliefs and attitudes of the mathematics teacher: A model. Journal of Education for Teaching, 15(1), 13-34. https://doi.org/10.1080/0260747890150102

Ernest, P. (1991). The Philosophy of Mathematics Education. Hampshire (UK): The Falmer Press.

Foss, D. H., \& Kleinsasser, R. C. (1996). Preservice elementary teachers' views of pedagogical and mathematical content knowledge. Teaching and Teacher Education, 12(4), 429-442. https://doi.org/10.1016/0742-051X(95)00049-P

Frank, M. L. (1990). What myths about mathematics are held and conveyed by teachers? Arithmetic Teacher, 37(5), 10-12.

Fullan, M. \& Stegelbauer, S. (1991). The new meaning of educational change. New York: Cassell.

Furinghetti, F., \& Pehkonen, E. (2002). Rethinking characterizations of beliefs. In Beliefs: $A$ hidden variable in mathematics education? (pp. 39-57). https://doi.org/10.1007/0306-47958-3 3

Furinghetti, F. (1996). A theoretical framework for teachers' conceptions. In E. Pehkonen (Ed.), Current State of Research on Mathematical Beliefs III. Proceedings of the MAVI-3 Workshop (pp.19-25). University of Helsinki. Department of Teacher Education. Research Report 170.

Goldin, G., Rösken, B., \& Törner, G. (2009). Beliefs-no longer a hidden variable in mathematical teaching and learning processes. In J. Masses \& W. Schlogmann (Eds.), 
Beliefs and attitudes in mathematics education (pp. 1-18). Rotterdam, The Netherlands: Sense Publishers. https://doi.org/10.1163/9789087907235 002

Gómez-Chacón, I. M., García-Madruga, J. A., Rodríguez, R., Vila, J. Ó., \& Elosúa, M. R. (2011). Mathematical beliefs and cognitive reflection: Do they predict academic achievement? In B. Roesken, \& M. Casper (Eds.), Current State of Research on Mathematical Beliefs XVII. Proceedings of the MAVI-17 (pp. 64-73). Ruhr-Universität Bochum, Germany.

Gómez-Chacón, I. M., \& García-Madruga, J. A. (2009). Mathematical beliefs questionnaire (Creemat). In I+D+i project: Cognition and education: working memory, reading comprehension and reasoning, from the Spanish Ministry of Science and Innovation.

Grossman, P. and S. S. S. (1995). Content as context: The role of school subjects in secondary school teaching. Educational Researcher, 24(8), 5-23. https://doi.org/10.2307/1176887

Hacıömeroğlu, G., \& Şahin-Taşkın, Ç. (2010). Sınıf öğretmeni adaylarının matematik öğretimi yeterlik inançları. Uludağ Üniversitesi Eğitim Fakültesi Dergisi, 23(2), 539555.

Handal, B., \& Herrington, A. (2003). Mathematics teachers' beliefs and curriculum reform. Mathematics Education Research Journal, 15(1), 59-69. https://doi.org/10.1007/BF03217369

Handal, B. (2003). Teachers' mathematical beliefs: A review. The Mathematics Educator, 13(2), 47-57. Retrieved From http://tme.journals.libs.uga.edu/index.php/ tme/article/view/131

House, J. D. (2006). Mathematics beliefs and achievement of elementary school students in Japan and the United States: Results from the Third International Mathematics and Science Study. The Journal of Genetic Psychology, 167(1), 31-45. https://doi.org/10.3200/GNTP.167.1.31-45

Işıksal, M., Kurt, G., Doğan, O., \& Çakıroğlu, E. (2007). İlköğretim Matematik Öğretmen Adaylarının Epistemolojik Kavramlamaları: Üniversite ve Sınıf Düzeyinin Etkisi. Ilköğretim Online, 6(2), 313-321.

Kagan, D. M. (1992). Implication of research on teacher belief. Educational Psychologist, 27(1), 65-90. https://doi.org/10.1207/s15326985ep2701 6

Kaiser, H. F. (1960). The application of electronic computers to factor analysis. Educational and Psychological Measurement, 20(1), 141-151. https://doi.org/10.1177/001316446002000116

Koehler, M. S. \& Grouws, D. A. (1992). Mathematics teaching practices and their effects. In D. A. Grouws (Ed.), Handbook of research in on mathematics teaching and learning (pp. 115-126). New York: Macmillan.

McLeod, D. (1992). Research on affect in mathematics education: A reconceptualization. In D. Grows (Ed.), Handbook of research on mathematics teaching and learning (pp. 575596). New York: McMillan

Memnun, D. S., \& Katranci, Y. (2012). A Research on the Beliefs about Mathematics Learning and Teacher Efficacy of Prospective Teachers in Turkey. World Journal of Education, 2(6), 66-78. https://doi.org/10.5430/wje.v2n6p66

Nespor, J. (1987). The role of beliefs in the practice of teaching. Journal of Curriculum Studies, 19(4), 317-328. https://doi.org/10.1080/0022027870190403

Op't Eynde, P., \& De Corte, E. (2003). Students' Mathematics-Related Belief Systems: Design and Analysis of a Questionnaire. Paper presented at the 2003 Annual Meeting of the American Educational Research Association, pp.21-25, Chicago.

Op't Eynde, P., De Corte, E., \& Verschaffel, L. (2002). Framing students' mathematics-related beliefs: A quest for conceptual clarity and a comprehensive categorization. In G.C. 
Leder, E. Pehkonen, \& G. Törner (Eds.), Beliefs: A hidden variable in mathematics education? (pp. 13-37). Dordrecht, The Netherlands: Kluwer Academic Publishers. https://doi.org/10.1007/0-306-47958-3 2

Pajares, M. F. (1992). Teachers' beliefs and educational research: Cleaning up a messy construct. Review of Educational Research, 62(3), 307-332. https://doi.org/10.3102/00346543062003307

Pehkonen, E. and Pietilä, A. (2003). On the relation between beliefs and knowledge in mathematics education. CERME3, Bellaria, Italy.

Pehkonen, E., \& Törner, G. (1996). Mathematical beliefs and different aspects of their meaning. International Reviews on Mathematical Education (ZDM), 28(4), 101-108.

Purnomo. W., Suryadi, D., \& Darwis, S. (2016). Examining pre-service elementary school teacher beliefs and instructional practices in mathematics class. International Electronic Journal of Elementary Education, 8(4), 629-642. Retrieved From https://www.iejee.com/index.php/IEJEE/article/view/137

Purnomo, Y. W. (2017). The complex relationship between teachers' mathematics-related beliefs and their practices in mathematics class. The New Educational Review, 47(1), 200-210. https://doi.org/10.15804/tner.2017.47.1.16

Rokeach, M. (1968). Beliefs, attitudes, and values. San Francisco (Ca): Jossey-Bass.

Schoenfeld, A. H. (1983). Beyond the purely cognitive: Belief systems, social cognitions, and metacognitions as driving forces in intellectual performance. Cognitive Science, 7(4), 329-363. https://doi.org/10.1016/S0364-0213(83)80003-2

Schoenfeld, A. H. (1985). Mathematical Problem Solving. Orlando (FL.): Academic Press.

Schoenfeld, A. H. (1987). What's all the fuss about metacognition? In A.H. Schoenfeld (Ed.), Cognitive Science and Mathematics Education (pp. 189-215). Hillsdale (NJ): Lawrence Erlbaum Associates

Shi, Q., Zhang, S., \& Lin, E. (2014). Relationships of new teachers' beliefs and instructional practices: Comparisons across four countries. Action in Teacher Education, 36(4), 322-341. https://doi.org/10.1080/01626620.2014.948228

Siswono, T. Y. E., Kohar, A. W., Kurniasari, I., \& Hartono, S. (2018). Inconsistency among beliefs, knowledge, and teaching practice in mathematical problem solving: A case study of a primary teacher. Southeast Asian Mathematics Education Journal, 7(2), 2739. Retrieved From http://journal.qitepinmath.org/index.php/seamej/article/ view $/ 51$

Skott, J. (2010). Shifting the direction of belief research: from beliefs to patterns of participation. In Pinto, M.F. \& Kawasaki, T.F. (Eds) Proceedings of the 34th Conference of the International Group for Psychology of Mathematics Education (pp. 193-200). Belo Horizonte, Brazil: PME.

Sosniak, L. A., Ethington, C. A., \& Varelas, M. (1991). Teaching mathematics without a coherent point of view: Findings from the IEA Second International Mathematics $\begin{array}{llll}\text { Study. J. } & \text { Curriculum } & \text { Studies, } & \text { 23(2), }\end{array}$ https://doi.org/10.1080/0022027910230202

Southwell, B., \& Khamis, M. (1992). Beliefs about mathematics and mathematics education. In K. Owens, B. Perry, \& B. Southwell (Eds.) Space, the first and final frontier. Proceedings of the 15th Annual Conference of the Mathematics Research Group of Australasia (pp. 497-509). Sydney: MERGA.

Stage, F. K., \& Kloosterman, P. (1992). Measuring beliefs about mathematical problem solving. School Science and Mathematics, 92(3), 109-115. https://doi.org/10.1111/i.1949-8594.1992.tb12154.x

Thompson, A. (1992). Teachers' Beliefs and Conceptions: A Synthesis of the Research. In D. 
A. Grouws (Ed.), Handbook of Research on Mathematics Teaching and Learning (pp. 127-146). New York: Macmillan

Thompson, A. G. (1991). The development of teachers' conceptions of mathematics teaching. Proceedings of the 13th Annual Conference of the North American Chapter of the International Group for the Psychology of Mathematics Education. (ERIC Document Reproduction Service No. ED 352274).

Xenofontos, C. (2018). Greek-Cypriot elementary teachers' epistemological beliefs about mathematics. Teaching and Teacher Education, 70(1), 47-57. https://doi.org/10.1016/j.tate.2017.11.007

Xie, S., \& Cai, J. (2018). Chinese Teachers' Beliefs About Mathematics Teaching. In The 21st Century Mathematics Education in China (pp. 413-427). https://doi.org/10.1007/978-3-662-55781-5 20 